\title{
Influence of Different Garlic Treatments on Controlling Basal Stem Rot, Root Rot and Infection by Broomrape in Geranium Plants.
}

Dewidar, A.A. ${ }^{1}$; Kenawy, A.G.M. ${ }^{1}$ and Ghebrial, E.W.R. ${ }^{2}$

1-Horticulture Research Institute, Agricultural Research Center, Giza, Egypt.

2-Plant Pathology Research Institute, Agricultural Research Center, Giza, Egypt.

T wo field experiments were conducted to evaluate the efficacy of different garlic treatments against basal stem rot, root rot and broomrape of geranium and its productivity at the Exp. Farm of Sids Hort. Res. Stat., Agric. Res. Center, Beni-Sweif governorate during 2016 and 2017 growing seasons. It was observed that using garlic as intercropping with geranium, soil amendment in addition to spraying garlic extract effectively controlled basal stem and root rot as well as decreased the infection by broomrape. These treatments enhanced plant growth, oil and its chemical composition, where, intercropping of garlic with geranium plants as a treatment gave the highest mean values of oil (\%) and oil yield ( $\mathrm{kg} / \mathrm{fed}$.), respectively for the two plant cuts followed by soil amendment with garlic and spraying geranium plants with garlic extract.

Keywords: garlic, basal stem rot; root rot; broomrape; intercropping; soil amendment; garlic extract; geranium.

Geranium (Pelargonium graveolens, L.) is a very important aromatic plant belongs to the Geraniaceae family, mainly cultivated for its essential oil (Eiasu et al., 2012), which possesses high economic value in international market because of its very profound and strong rose-like fragrance used in perfumery, cosmetics and other flavoring industries in addition to its medicinal importance like wounds healing, ulcers disorders as well as treatment of dysentery, diarrhea and colic (Matthews, 1995 and Prins et al., 2010). Geranium is now substantial aromatherapy oil used as balancing oil for both mind and body (Dorman and Deans 2000). Essential oil which is mainly extracted from leaves by steam and /or water distillation techniques (Rajeswara Rao et al., 1996) positively correlates to herbage yield (Singh, 1999 and Motsa et al., 2006). Geranium is attacked by basal stem rot and root rot caused by Fusarium spp., Pythium ultimum, Rhizoctonia solani and Machrophomina phaseolina, which considered the most serious pathogens affecting the horticultural crop in Egypt and worldwide (Kalra et al., 1992; El-Gamal, 1995; Haggag and Abdel-Latif, 2001 and Adolf, 2016) leading to significant losses every season. 
Orobanche species are obligate chlorophyll-lacking root parasites, which cause great damage to many cultivated crops all over the world (Joel et al., 2007 and Parker, 2009 and Parker, 2012). Losses in some crops can reach more than 95\% in highly infested fields (Abbes et al., 2007and Kharrat et al., 2010) depending on host susceptibility, level of infestation, and environmental conditions. In Egypt, geranium is severely attacked by $O$. ramose causing in some fields important yield losses. A wide variety of control methods, i.e., physical, cultural, chemical, and biological methods have been explored against soil borne pathogens and broomrape, but most of them are ineffective or insufficiently selective to the majority of susceptible crops (Joel et al., 2007). The lack of efficient control methods can lead to a significant build up the weed seed bank. The seeds can remain viable for 20 years or more in the absence of the host plant (Kebreab and Murdoch, 1999). The effect of trap crops on broomrape plays great role in stimulating seed germination, but do not attacked themselves by the parasites. Crop rotation with potential trap crops for number of years, say 5-10 years deplete soil seed bank of Orobanche infestation. Orobanche parasitic weeds assumed to be reduced by $30 \%$ in every growing season, growing trap crops for two consecutive seasons reduced soil seed bank of Orobanche species by 60\% (Linke et al., 1991 and Lüpez-Granados \& Garcfa-Torres, 1991). Trap crops or non-host plants may stimulate the germination of its seeds but cannot infect and thus reduce density of seeds in the soil due to suicidal germination (Acharya, 2013). Garlic (Allium sativum) as trap crop has been shown to be effective on controlling broomrape (Abebe et al., 2005) and soil borne fungal pathogens (Mercado and Rodriguez, 2001 and Sealy et al., 2007). As well as improves plant growth (Noghani et al., 2013, Singh et al., 2013 and Cheng et al., 2016).

This study was conducted to evaluate the potential of different treatments of garlic to control basal stem rot, root rot and broomrape in geranium and their effects on its productivity.

\section{Materials and Methods}

Two field experiments were conducted under natural infestation with the causal of basal stem rot and root rot of geranium and the broomrape in the Exp. Farm of Sids Hort. Res. Stat., Agric. Res. Center, Beni-Sweif governorate during 2016 and 2017 growing seasons to evaluate the efficacy of different treatments of garlic against these diseases and the parasite broomrape as well as their effects on productivity of geranium. Soil texture was a clay loam and was analyzed for physical and chemical properties (Jackson, 1958) and the results are presented in (Table, 1).

Table (1). Analysis of the soil in 2016 and 2017.

\begin{tabular}{|c|c|c|c|c|c|c|c|c|c|c|}
\hline \multirow{3}{*}{ Seasons } & \multicolumn{3}{|c|}{ Particle size distribution* } & \multirow{3}{*}{$\begin{array}{c}\text { Textural } \\
\text { Class }\end{array}$} & \multicolumn{6}{|c|}{ Chemical properties** } \\
\hline & \multirow{2}{*}{$\begin{array}{c}\text { Clay } \\
\%\end{array}$} & \multirow{2}{*}{$\begin{array}{c}\text { Silt } \\
\%\end{array}$} & \multirow{2}{*}{$\begin{array}{c}\text { Sand } \\
\%\end{array}$} & & \multirow{2}{*}{$\begin{array}{c}\mathrm{OM} \\
\%\end{array}$} & \multirow{2}{*}{$\begin{array}{l}\mathrm{EC}, \mathrm{dSm}^{-1} \\
\text { (at } 25^{\circ} \mathrm{C} \text { ) }\end{array}$} & \multicolumn{3}{|c|}{ Available (ppm) } & \multirow[t]{2}{*}{$\mathrm{pH}$} \\
\hline & & & & & & & $\mathrm{N}$ & $\mathrm{P}$ & $\mathrm{K}$ & \\
\hline & 48.78 & 33.11 & 1811 & & 1.68 & 1.12 & 41.00 & 11.18 & 210.3 & 7.7 \\
\hline 2017 & 48.10 & 33.61 & 18.29 & Clay & 1.80 & 1.03 & 36.00 & 10.60 & 224.6 & 7.8 \\
\hline
\end{tabular}

Egypt. J. Phytopathol., Vol. 47, No. 1 (2019) 
Garlic cloves (cv. Balady) and geranium cuttings $15 \mathrm{~cm}$ long with at least three leaves taken from stock plant stems were obtained from the Exp. Farm of Sids Hort. Res. Stat. The experiment was designed in a randomized complete blocks design, with three replications in plots $3 \times 3.5 \mathrm{~m}$ containing 5 rows $70 \mathrm{~cm}$ apart. During both experimental seasons, the following treatments of garlic were applied as follows:

T1: Cuttings treatment, soaking in garlic extract + foliar spray with garlic extract (5\%).

T2: Intercropping of garlic with geranium.

T3: Soil amendment with air dried garlic leaves.

T4: Soil amendment with air dried garlic leaves + foliar spray with garlic extract $(5 \%)$.

T5: The fungicide Rizolex-T + the herbicide Roundup star.

T6: Untreated as control.

For preparation of garlic extract: Fifty grams of garlic cloves were homogenized by blender in $200 \mathrm{ml}$ of ethanol (96\%) and distilled water (20:80, v:v) for $10 \mathrm{~min}$, then left in dark glass bottles for $72 \mathrm{~h}$ for tissue maceration. The extracts were filtered through thin cheesecloth sheets. The final extracts were collected separately in other dark glass bottles and left at room temperature for ethanol evaporation. The collected extracts were then stored in a refrigerator at $5^{\circ} \mathrm{C}$ until needed (El-Mougy and Abdel-Kader, 2007).

For intercropping: garlic cloves were planted in the opposite side of row at 15 $\mathrm{cm}$ apart on $15^{\text {th }}$ September and geranium cuttings were planted in $1^{\text {st }}$ of November in the two seasons.

For soil amendments: Leaves of garlic (collected before ten days from harvest) were air-dried under shade and grounded. The specified dried and grounded leaves were then mixed thoroughly in a layer $15 \mathrm{~cm}$ below the soil surface at the rate of 4 ton per fed., $90 \mathrm{~kg} / \mathrm{fed}$. of urea were added to amended soil and watered to facilitate decomposition of organic matter (Hussain et al., 2011). Two weeks after amendment, geranium cuttings were planted in amended plots.

In each season, the soil was mechanically ploughed and planked twice. During the preparation for cultivation, calcium super-phosphate $\left(15.5 \% \mathrm{P}_{2} \mathrm{O}_{5}\right)$ was added at the rate of $200 \mathrm{~kg} / \mathrm{fed}$. Geranium cuttings were soaked in garlic extract $(5 \%)$ for half an hour before planting. Cuttings soaked in the fungicide Rizolex-T 50\% WP. (active ingredient: Tolclofos-methyl + thiram), Sumitomo Chemical Company Co, Ltd, Osaka, Japan. at the concentration of $2 \mathrm{~g} / \mathrm{l}$ for half hour were included as a chemical control. The treated and untreated cuttings were planted on $1^{\text {st }}$ of November in the two experimental seasons on rows at $30 \mathrm{~cm}$ spacing between cuttings. The herbicide Roundup star (Glyphosate-K 44.1) at the rate of $50 \mathrm{~cm}^{3} / \mathrm{fed}$. was applied to geranium plants as soon as the broomrape appears above the soil surface and the second treatment was after one month from the first application. 
Other weeds were removed by manual operations as needed and plants were irrigated regularly as necessary, throughout the growing season in order to maintain constant growth. The plants were sprayed with the garlic extract $(5 \%)$ every 15 days one month after planting. All agricultural practices were carried out according to the recommendation of Agric. Ministry for the production of garlic and geranium crops.Disease incidence and severity were estimated as follow:

Disease incidence:

The percentages of disease incidence were recorded as the number of diseased plants relative to the number of growing plants for each treatment, and then the average of disease incidence was calculated. Reduction in disease incidence was calculated using the following formula:

$$
\text { Reduction } \%=[\mathrm{C}-\mathrm{T}] / \mathrm{C} \times 100
$$

Where: $\mathrm{C}$ and $\mathrm{T}$ are the percentages of disease incidence in control and treated plants, respectively.

Disease severity:

Disease severity was estimated at the end of each experiment based on the progress of yellowing and root rot and rotting using the rating scale according to a 0 5 scale of Shahzad \& Ghaffar (1992) with minor modification where $0=0,1=>0-10$, $2=>10-25,3=>25-50,4=>50-75$ and $5=>75-100 \%$.

$$
\text { Disease severity } \%=[\Sigma(\mathrm{n} \times \mathrm{c})] /(\mathrm{N} \times \mathrm{C}) \times 100
$$

Where: $\mathrm{n}=$ Number of infected plants, $\mathrm{c}=$ Category number, $\mathrm{N}=$ Total number of examined plants and $\mathrm{C}=$ The highest category number of infections.

\section{Plant samples and measurements}

A random sample of five plants was taken from each experimental treatment during each of the cuts on $1^{\text {st }}$ July and $1^{\text {st }}$ October for blooming of geranium plants at the two seasons. The following parameters, i.e., plant height $(\mathrm{cm})$, number of branches/plant, herb fresh weights (g/plant) and ton /fed. as well as chlorophyll A and $\mathrm{B}$ and carotenoids content and essential oil percentage, oil yield and its components.

\section{Essential oils extraction:}

One hundred gram of fresh geranium leaves were hydrodistilled in a Clevenger apparatus according to Guenther (1961) in triplicate. Essential oil percentage was determined. The essential oils were collected and dehydrated over anhydrous sodium sulphate and kept in a refrigerator until GC analysis.

Gas chromatographic analysis $(G C)$ of the essential oils:

The GC analysis of the volatile oil samples was carried out using gas chromatography instrument. DsChrom 6200 Gas Chromatograph equipped with a flame ionization detector, Column: BPX-5, 5\% phenyl (equiv.) polysillphenylenesiloxane $30 \mathrm{~m} \times 0.25 \mathrm{~mm}$ ID x $0.25 \mu \mathrm{m}$ film., Sample size: 1il, Temperature program 
ramp increases with a rate of $10^{\circ} \mathrm{C} / \mathrm{min}$ from $70^{\circ}$ to $200^{\circ} \mathrm{C}$, Detector temperature (FID): $280^{\circ} \mathrm{C}$, Carrier gas: nitrogen, Flow rate: $\mathrm{N} 230 \mathrm{ml} / \mathrm{min} ; \mathrm{H} 230 \mathrm{ml} / \mathrm{min}$; air $300 \mathrm{ml} / \mathrm{min}$. Main compounds of the volatile oils were identified by matching their retention times with those of the authentic samples injected under the same conditions. The relative percentage of each compound was calculated from the area of the peak corresponding to each compound.

The isolation of essential oils and gas chromatographic analysis were carried out at the Medicinal and Aromatic Plants Res. Dept. Laboratory, Hort. Res. Ins., ARC.

\section{Statistical analysis}

Data collected were analyzed using analysis of variance (ANOVA) using MSTAT-C software. Differences among treatments means were performed by Duncan's multiple range test (Snedecor and Cochran, 1989).

\section{Results}

Data in Table (2) indicate that geranium plants had significant lower basal stem rot levels due to the different garlic treatments tested compared with untreated control. Geranium plants intercropped with garlic showed the highest effect on reducing disease incidence, which caused $80.0 \%$ in the $1^{\text {st }}$ growing season and $87.6 \%$ reduction in the $2^{\text {nd }}$ growing season. The efficacy was similar the efficiency of the fungicide treatment (Rizolex-T), which caused 86.8 and $93.6 \%$ reduction in basal stem rot incidence during the two growing seasons, respectively. However, soil amended with garlic and sprayed with garlic extract resulted in moderate reduction to the diseased plants, i.e., $73.2 \%$ in the $1^{\text {st }}$ growing season and $81.3 \%$ in the $2^{\text {nd }}$ growing season followed by the treatment of soil amended with garlic only with no significant difference between them. The least effective treatment was cuttings treatment, soaking in garlic extract + foliar spray which recorded 46.8 and $56.2 \%$ reduction in disease incidence in the two growing seasons, respectively.

Results in Tables ( 3 and 4) demonstrate that all garlic treatments significantly reduced the incidence and severity of root rot of geranium plants compared to untreated control. In the $1^{\text {st }}$ growing season, the highest effective treatment for reducing incidence and severity of root rot was the treatment of the fungicide Rizolex-T + the herbicide Roundup star followed by intercropping of garlic with geranium, being 76.0 and $65.6 \%$ disease incidence and 90.3 and $83.6 \%$ disease severity. Moderate reduction in geranium root rot was observed when geranium sown in soil amended with garlic then sprayed the geranium leaves with garlic extract. This action was followed by amendment the soil with garlic only without significant differences. The corresponding mean values of reduction in disease incidence were 45.0 and $39.1 \%$ and those of disease severity were 60.2 and $52.8 \%$, respectively. Meanwhile, treatment of geranium cuttings and spraying the leaves 
with garlic extract gave the lowest reduction in this concern, being 12.8 and $22.7 \%$, respectively. The same trend was observed in the $2^{\text {nd }}$ growing season.

Table (2): Effect of different garlic treatments on incidence of geranium basal stem rot during the two growing seasons (2016 and 2017).

\begin{tabular}{|c|c|c|c|c|}
\hline \multirow{2}{*}{ Treatments } & \multicolumn{2}{|c|}{$1^{\text {st }}$ season } & \multicolumn{2}{c|}{$2^{\text {nd }}$ season } \\
\cline { 2 - 5 } & $\begin{array}{c}\text { Disease } \\
\text { incidence } \%\end{array}$ & $\begin{array}{c}\text { Reduction* } \\
\%\end{array}$ & $\begin{array}{c}\text { Disease } \\
\text { incidence } \%\end{array}$ & $\begin{array}{c}\text { Reduction* } \\
\%\end{array}$ \\
\hline $\begin{array}{c}\text { Cuttings treatment } \\
\text { + foliar spray }\end{array}$ & $13.3 \mathrm{~b}$ & 46.8 & $11.7 \mathrm{~b}$ & 56.2 \\
\hline Intercropping & $5.0 \mathrm{de}$ & 80.0 & $3.3 \mathrm{de}$ & 87.6 \\
\hline $\begin{array}{c}\text { Soil amended with } \\
\text { garlic }\end{array}$ & $8.3 \mathrm{c}$ & 66.8 & $6.7 \mathrm{c}$ & 74.9 \\
\hline $\begin{array}{c}\text { Soil amended with } \\
\text { garlic + foliar } \\
\text { spray }\end{array}$ & $6.7 \mathrm{~cd}$ & 73.2 & $5.0 \mathrm{~cd}$ & 81.3 \\
\hline $\begin{array}{c}\text { Rizolex-T + } \\
\text { Roundup star }\end{array}$ & $3.3 \mathrm{e}$ & 86.8 & $1.7 \mathrm{e}$ & 93.6 \\
\hline Control & $25.0 \mathrm{a}$ & --- & $26.7 \mathrm{a}$ & --- \\
\hline
\end{tabular}

* Reduction \% related to the control.

Means designed by the same letter at each cell are not significantly different at the $5 \%$ level according to Duncan's multiple range test.

Table (3): Effect of different garlic treatments on incidence of geranium root rot during the two growing seasons (2016 and 2017).

\begin{tabular}{|c|c|c|c|c|}
\hline \multirow[b]{2}{*}{ Treatments } & \multicolumn{2}{|c|}{$1^{\text {st }}$ season } & \multicolumn{2}{|c|}{$2^{\text {nd }}$ season } \\
\hline & $\begin{array}{c}\text { Disease } \\
\text { incidence } \%\end{array}$ & $\begin{array}{c}\text { Reduction* } \\
\%\end{array}$ & $\begin{array}{c}\text { Disease } \\
\text { incidence } \%\end{array}$ & $\begin{array}{c}\text { Reduction* } \\
\%\end{array}$ \\
\hline $\begin{array}{l}\text { Cuttings treatment } \\
+ \text { foliar spray }\end{array}$ & $31.2 b$ & 12.8 & $28.3 b$ & 26.7 \\
\hline Intercropping & $12.3 \mathrm{de}$ & 65.6 & $8.6 \mathrm{de}$ & 77.7 \\
\hline $\begin{array}{l}\text { Soil amended with } \\
\text { garlic }\end{array}$ & $21.8 \mathrm{c}$ & 39.1 & $17.9 \mathrm{c}$ & 53.6 \\
\hline $\begin{array}{l}\text { Soil amended with } \\
\text { garlic + foliar } \\
\text { spray }\end{array}$ & $19.7 \mathrm{c}$ & 45.0 & $14.0 \mathrm{c}$ & 63.7 \\
\hline $\begin{array}{l}\text { Rizolex-T + } \\
\text { Roundup star }\end{array}$ & $8.6 \mathrm{e}$ & 76.0 & $6.8 \mathrm{e}$ & 86.4 \\
\hline Control & $35.8 \mathrm{a}$ & --- & $38.6 a$ & --- \\
\hline
\end{tabular}

* Reduction $\%$ related to the control.

Means designed by the same letter at each cell are not significantly different at the $5 \%$ level according to Duncan's multiple range test.

Egypt. J. Phytopathol., Vol. 47, No. 1 (2019) 
Table (4): Effect of different garlic treatments on disease severity of geranium root rot during the two growing seasons (2016 and 2017).

\begin{tabular}{|c|c|c|c|c|}
\hline \multirow[b]{2}{*}{ Treatments } & \multicolumn{2}{|c|}{$1^{\text {st }}$ season } & \multicolumn{2}{|c|}{$2^{\text {nd }}$ season } \\
\hline & $\begin{array}{c}\text { Disease } \\
\text { severity } \% \\
\end{array}$ & $\begin{array}{c}\text { Reduction* } \\
\% \\
\end{array}$ & $\begin{array}{c}\text { Disease } \\
\text { severity } \% \\
\end{array}$ & $\begin{array}{c}\text { Reduction* } \\
\%\end{array}$ \\
\hline $\begin{array}{l}\text { Cuttings treatment } \\
+ \text { foliar spray }\end{array}$ & $20.8 b$ & 22.7 & $16.5 b$ & 42.9 \\
\hline Intercropping & $4.4 \mathrm{de}$ & 83.6 & 3.0de & 89.6 \\
\hline $\begin{array}{l}\text { Soil amended with } \\
\text { garlic }\end{array}$ & $12.7 \mathrm{c}$ & 52.8 & $9.3 \mathrm{c}$ & 67.8 \\
\hline $\begin{array}{c}\text { Soil amended with } \\
\text { garlic }+ \text { foliar } \\
\text { spray }\end{array}$ & $10.7 \mathrm{c}$ & 60.2 & $7.5 \mathrm{c}$ & 74.0 \\
\hline $\begin{array}{l}\text { Rizolex-T + } \\
\text { Roundup star }\end{array}$ & $2.6 \mathrm{e}$ & 90.3 & $2.1 \mathrm{e}$ & 92.7 \\
\hline Control & $26.9 a$ & --- & $28.9 a$ & --- \\
\hline
\end{tabular}

* Reduction \% related to the control.

Means designed by the same letter at each cell are not significantly different at the $5 \%$ level according to Duncan's multiple range test.

The broomrape spikes count, and weight/plot were significantly reduced due to garlic treatments tested than the untreated control (Table, 5). Among garlic treatments, intercropping of garlic with geranium plants significantly showed very remarkable reduction in spikes count and weight of broomrape by 30.3 and $40.5 \%$, respectively in the $1^{\text {st }}$ growing season and generally the fungicide Rizolex-T + the herbicide Roundup star treatment was the most efficient in this regard, which significantly reduced the broomrape spikes count by $41.2 \%$ and the weight by $57.1 \%$. Moderate reductions were found in plots received garlic as soil amendment + spraying geranium plants with garlic extract followed by treatment of soil amendment with garlic only without significant difference. The corresponding mean values of reduction in spikes count were 17.3, 15.9\% and weight, being 30.2, 28.6, respectively. Treating geranium cuttings and spraying the leaves with garlic extract was the lowest efficient treatment in controlling broomrape, which statistically was not differed than the control treatment. The same trend was observed in the $2^{\text {nd }}$ growing season. 
Table (5): Effect of different garlic treatments on some broomrape parameters during the two growing seasons (2016 and 2017).

\begin{tabular}{|c|c|c|c|c|c|c|c|c|}
\hline \multirow[b]{2}{*}{ Treatments } & \multicolumn{4}{|c|}{$1^{\text {st }}$ season } & \multicolumn{4}{|c|}{$2^{\text {nd }}$ season } \\
\hline & 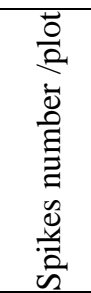 & 葛 & $\begin{array}{l}\frac{\overrightarrow{0}}{0} \\
\frac{000}{2} \frac{0}{20} \\
\frac{0}{2}\end{array}$ & 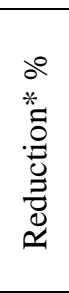 & 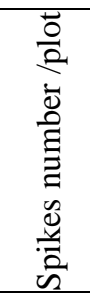 & 萼 & 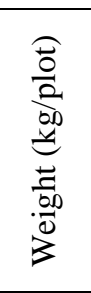 & 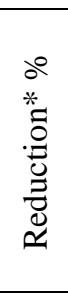 \\
\hline $\begin{array}{l}\text { Cuttings treatment } \\
+ \text { foliar spray }\end{array}$ & $1064 b$ & 4.3 & $11.7 \mathrm{a}$ & 7.1 & $1045 b$ & 23.8 & $10.8 \mathrm{~b}$ & 23.4 \\
\hline Intercropping & $775 d$ & 30.3 & $7.5 \mathrm{c}$ & 40.5 & $579 d$ & 57.8 & $6.7 d$ & 52.5 \\
\hline $\begin{array}{l}\text { Soil amended with } \\
\text { garlic }\end{array}$ & $935 c$ & 15.9 & $9.0 \mathrm{~b}$ & 28.6 & $857 \mathrm{c}$ & 37.5 & $8.4 \mathrm{c}$ & 40.4 \\
\hline $\begin{array}{c}\text { soil amended with } \\
\text { garlic }+ \text { foliar } \\
\text { spray }\end{array}$ & $920 \mathrm{c}$ & 17.3 & $8.8 \mathrm{bc}$ & 30.2 & $844 c$ & 38.5 & $7.8 \mathrm{~cd}$ & 44.7 \\
\hline $\begin{array}{l}\text { Rizolex-T + } \\
\text { Roundup star }\end{array}$ & $654 \mathrm{e}$ & 41.2 & $5.4 \mathrm{~d}$ & 57.1 & $508 \mathrm{e}$ & 63.0 & $4.2 \mathrm{e}$ & 70.2 \\
\hline Control & $1112 \mathrm{a}$ & --- & $12.6 \mathrm{a}$ & --- & $1372 \mathrm{a}$ & --- & $14.1 \mathrm{a}$ & --- \\
\hline
\end{tabular}

* Reduction \% related to the control.

Means designed by the same letter at each cell are not significantly different at the $5 \%$ level according to Duncan's multiple range test.

\section{Effect of different garlic treatments on plant growth and yield parameters}

Results presented in Table (6) indicate that the different garlic treatments tested significantly increased geranium plant height $(\mathrm{cm})$ and number of branches/plant compared to the untreated control. In the $1^{\text {st }}$ growing season, the highest geranium plants and maximum number of branches per plant were recorded by fungicide and herbicide treatment followed by intercropping of garlic with geranium plants, without significant differences. The corresponding mean values for plant height were 98.00, $72.67 \mathrm{~cm}$ for the first cut \& 94.00, $71.67 \mathrm{~cm}$ for the second cut and No. of branches, being 20.00, $25.00 \& 17.00,21.33$ for the two plant cuts, respectively. While, treated geranium cuttings and spraying the leaves with garlic extract gave the least plant height, being 82.00, $56.67 \mathrm{~cm}$ and No. of branches per plant, being 13.67 and 17.33 , respectively for the two plant cuts. The same trend was observed in the second growing season.

Egypt. J. Phytopathol., Vol. 47, No. 1 (2019) 
Table (6): Effect of different garlic treatments on plant height $(\mathrm{cm})$ and number of branches/plant for geranium during the two growing seasons (2016 and 2017).

\begin{tabular}{|c|c|c|c|c|}
\hline \multirow{2}{*}{ Treatments } & \multicolumn{2}{|c|}{ Plant height $(\mathrm{cm})$} & \multicolumn{2}{|c|}{$\begin{array}{c}\text { Number of } \\
\text { branches/plant }\end{array}$} \\
\hline & $1^{\text {st }}$ cut & $2^{\text {nd }}$ cut & $1^{\text {st }}$ cut & $2^{\text {nd }}$ cut \\
\hline & \multicolumn{4}{|c|}{$1^{\text {st }}$ season } \\
\hline $\begin{array}{l}\text { Cutting treatment }+ \text { foliar } \\
\text { spray }\end{array}$ & $82.00 \mathrm{c}$ & $56.67 d$ & $13.67 \mathrm{bc}$ & $17.33 d$ \\
\hline Intercropping & 94.00ab & $71.67 \mathrm{ab}$ & $17.00 \mathrm{ab}$ & $21.33 b$ \\
\hline Soil amended with garlic & $87.67 \mathrm{bc}$ & $62.33 c$ & $14.67 \mathrm{bc}$ & $18.67 \mathrm{c}$ \\
\hline $\begin{array}{l}\text { Soil amended with garlic }+ \\
\text { foliar spray }\end{array}$ & $87.67 \mathrm{bc}$ & $66.67 \mathrm{bc}$ & $16.00 \mathrm{~b}$ & $20.33 b$ \\
\hline Rizolex-T + Roundup star & $98.00 \mathrm{a}$ & $72.67 \mathrm{a}$ & $20.00 \mathrm{a}$ & $25.00 \mathrm{a}$ \\
\hline Control & $74.00 \mathrm{~d}$ & $53.00 \mathrm{~d}$ & $11.33 \mathrm{c}$ & $15.00 \mathrm{e}$ \\
\hline & \multicolumn{4}{|c|}{$2^{\text {nd }}$ season } \\
\hline $\begin{array}{l}\text { Cutting treatment }+ \text { foliar } \\
\text { spray }\end{array}$ & $70.67 d$ & $60.67 \mathrm{c}$ & $12.33 d$ & $15.00 \mathrm{~cd}$ \\
\hline Intercropping & 78.00ab & $72.67 \mathrm{a}$ & $17.33 \mathrm{a}$ & $19.67 \mathrm{ab}$ \\
\hline Soil amended with garlic & $73.33 \mathrm{~cd}$ & $65.33 b$ & $13.33 \mathrm{c}$ & $16.33 \mathrm{bc}$ \\
\hline $\begin{array}{l}\text { Soil amended with garlic + } \\
\text { foliar spray }\end{array}$ & $74.67 \mathrm{bc}$ & $71.67 \mathrm{a}$ & $15.33 b$ & $16.67 \mathrm{bc}$ \\
\hline Rizolex-T + Roundup star & $80.67 \mathrm{a}$ & $74.00 \mathrm{a}$ & $18.00 \mathrm{a}$ & $20.67 \mathrm{a}$ \\
\hline Control & $64.00 \mathrm{e}$ & $50.00 \mathrm{~d}$ & $10.33 \mathrm{e}$ & $12.33 \mathrm{~d}$ \\
\hline
\end{tabular}

Means designed by the same letter at each cell are not significantly different at the $5 \%$ level according to Duncan's multiple range test.

It is obvious from data illustrated in Table (7) that all tested treatments of garlic showed an increase in the fresh weight of herb/plant. In the first growing season, the highest fresh weight values were obtained with the fungicide and herbicide treatment followed by intercropping of garlic with geranium plants with significant difference between both. The corresponding mean values of herb fresh weight per plant were 920.0, $890.0 \mathrm{~g}$ whereas, they were 18.40 and17.80 ton per fed., respectively in the first cut. Meanwhile, these figures were 760.0, 726.7 g/plant and 15.20, 14.53 ton/fed., respectively in the second plant cut. Moderate mean values of fresh weight of the herb for the two cuts were obtained due to soil amendment with garlic and spraying geranium plants with garlic extract followed by soil amendment with garlic only treatment. Moreover, treated geranium cuttings and spraying the leaves with garlic extract gave the lowest mean values of herb fresh weight $(780.0,620.0 \mathrm{~g} / \mathrm{plant}$ and $15.60,12.40$ ton/fed., respectively for the two plant cuts). The same trend was also true for the second growing season. 
Table (7): Effect of different garlic treatments on geranium fresh weight during the two growing seasons (2016 and 2017).

\begin{tabular}{|c|c|c|c|c|}
\hline \multirow{2}{*}{ Treatments } & \multicolumn{2}{|c|}{$\begin{array}{c}\text { Herb fresh weight } \\
(\mathrm{g} / \text { plant })\end{array}$} & \multicolumn{2}{|c|}{$\begin{array}{l}\text { Herb fresh weight } \\
\text { (ton/fed.) }\end{array}$} \\
\hline & $1^{\text {st }}$ cut & $2^{\text {nd }}$ cut & $1^{\text {st }}$ cut & $2^{\text {nd }}$ cut \\
\hline & \multicolumn{4}{|c|}{$1^{\text {st }}$ season } \\
\hline $\begin{array}{l}\text { Cutting treatment + } \\
\text { foliar spray }\end{array}$ & $780.0 \mathrm{e}$ & $620.0 \mathrm{e}$ & $15.60 \mathrm{e}$ & $12.40 \mathrm{e}$ \\
\hline Intercropping & $890.0 \mathrm{~b}$ & $726.7 \mathrm{~b}$ & $17.80 \mathrm{~b}$ & $14.53 \mathrm{~b}$ \\
\hline $\begin{array}{l}\text { Soil amended with } \\
\text { garlic }\end{array}$ & $830.0 d$ & $670.0 d$ & $16.60 \mathrm{~d}$ & $13.40 \mathrm{~d}$ \\
\hline $\begin{array}{l}\text { Soil amended with } \\
\text { garlic + foliar spray }\end{array}$ & $863.3 \mathrm{c}$ & $693.3 \mathrm{c}$ & $17.27 \mathrm{c}$ & $13.87 \mathrm{c}$ \\
\hline $\begin{array}{c}\text { Rizolex-T + Roundup } \\
\text { star }\end{array}$ & $920.0 \mathrm{a}$ & $760.0 \mathrm{a}$ & $18.40 \mathrm{a}$ & $15.20 \mathrm{a}$ \\
\hline Control & $708.3 \mathrm{f}$ & $506.7 \mathrm{f}$ & $14.17 \mathrm{f}$ & $10.13 \mathrm{f}$ \\
\hline & \multicolumn{4}{|c|}{$2^{\text {nd }}$ season } \\
\hline $\begin{array}{l}\text { Cutting treatment }+ \\
\text { foliar spray }\end{array}$ & $670.0 d$ & $520.0 d$ & $13.40 \mathrm{~d}$ & $10.40 \mathrm{~d}$ \\
\hline Intercropping & $766.7 \mathrm{~b}$ & $620.0 \mathrm{~b}$ & $15.33 \mathrm{~b}$ & $12.40 \mathrm{~b}$ \\
\hline $\begin{array}{l}\text { Soil amended with } \\
\text { garlic }\end{array}$ & $710.0 \mathrm{c}$ & $543.3 d$ & $14.20 \mathrm{c}$ & $10.87 \mathrm{~d}$ \\
\hline $\begin{array}{l}\text { Soil amended with } \\
\text { garlic + foliar spray }\end{array}$ & $730.0 \mathrm{c}$ & $583.3 \mathrm{c}$ & $14.60 \mathrm{c}$ & $11.67 \mathrm{c}$ \\
\hline $\begin{array}{c}\text { Rizolex-T + Roundup } \\
\text { star } \\
\end{array}$ & $790.0 \mathrm{a}$ & $656.7 \mathrm{a}$ & $15.80 \mathrm{a}$ & $13.13 \mathrm{a}$ \\
\hline Control & $620.0 \mathrm{e}$ & $463.3 \mathrm{e}$ & $12.40 \mathrm{e}$ & $9.27 \mathrm{e}$ \\
\hline
\end{tabular}

Means designed by the same letter at each cell are not significantly different at the $5 \%$ level according to Duncan's multiple range test.

Regarding to oil percentage and oil yield of geranium, the tested garlic treatments resulted in a significant increment in oil \% and oil yield $(\mathrm{kg} / \mathrm{fed}$.$) in both$ seasons as shown in Table (8). In the first growing season, intercropping of garlic with geranium plants treatment gave the highest mean values of oil \% $(0.19 \& 0.18$ $\%)$ and oil yield $(33.83 \& 26.20 \mathrm{~kg} / \mathrm{fed}$., respectively for the two plant cuts followed by soil amendment with garlic and spraying geranium plants with garlic extract treatment without significant differences between them, being $0.19 \& 0.18 \%$ oil percentage and $32.10 \& 24.47 \mathrm{~kg} / \mathrm{fed}$. oil yield, respectively for the two plant cuts. Whereas treated geranium cutting and spraying the plants with garlic extract gave the lowest mean values of oil percent $(0.15 \& 0.17 \%)$ and oil yield $(26.47 \& 21.43$ $\mathrm{kg} /$ fed.), respectively for the two plant cuts. The same trend was observed in the second growing season.

Egypt. J. Phytopathol., Vol. 47, No. 1 (2019) 
Table (8): Effect of different garlic treatments on oil percentage and oil yield of geranium during the two growing seasons (2016 and 2017).

\begin{tabular}{|c|c|c|c|c|}
\hline \multirow{2}{*}{ Treatments } & \multicolumn{2}{|c|}{ Oil \% } & \multicolumn{2}{|c|}{ Oil yield (kg/fed.) } \\
\hline & $1^{\text {st }}$ cut & $2^{\text {nd }}$ cut & $1^{\text {st }}$ cut & $2^{\text {nd }}$ cut \\
\hline \multicolumn{5}{|c|}{$1^{\text {st }}$ season } \\
\hline $\begin{array}{l}\text { Cutting treatment }+ \text { foliar } \\
\text { spray }\end{array}$ & $0.15 \mathrm{c}$ & $0.17 \mathrm{a}$ & $26.47 \mathrm{bc}$ & $21.43 \mathrm{c}$ \\
\hline Intercropping & $0.19 \mathrm{a}$ & $0.18 \mathrm{a}$ & $33.83 \mathrm{a}$ & $26.20 \mathrm{a}$ \\
\hline Soil amended with garlic & $0.18 \mathrm{ab}$ & $0.18 \mathrm{a}$ & $28.07 \mathrm{ab}$ & $24.47 \mathrm{ab}$ \\
\hline $\begin{array}{c}\text { Soil amended with garlic } \\
\text { + foliar spray }\end{array}$ & $0.19 \mathrm{a}$ & $0.18 \mathrm{a}$ & $32.10 \mathrm{ab}$ & 24.60ab \\
\hline $\begin{array}{c}\text { Rizolex-T + Roundup } \\
\text { star }\end{array}$ & $0.16 b c$ & $0.15 b$ & $29.47 \mathrm{ab}$ & $22.80 \mathrm{bc}$ \\
\hline Control & $0.15 \mathrm{c}$ & $0.14 \mathrm{~b}$ & $21.77 \mathrm{c}$ & $14.50 \mathrm{~d}$ \\
\hline \multicolumn{5}{|c|}{$2^{\text {nd }}$ season } \\
\hline $\begin{array}{l}\text { Cutting treatment }+ \text { foliar } \\
\text { spray }\end{array}$ & $0.15 \mathrm{ab}$ & $0.12 \mathrm{ab}$ & $20.57 \mathrm{ab}$ & $14.07 \mathrm{~b}$ \\
\hline Intercropping & $0.17 \mathrm{a}$ & $0.14 \mathrm{a}$ & $26.10 \mathrm{a}$ & $17.73 \mathrm{a}$ \\
\hline Soil amended with garlic & $0.16 a b$ & $0.13 \mathrm{a}$ & $23.40 \mathrm{a}$ & $14.23 \mathrm{~b}$ \\
\hline $\begin{array}{l}\text { Soil amended with garlic } \\
+ \text { foliar spray }\end{array}$ & $0.17 \mathrm{a}$ & $0.14 \mathrm{a}$ & $24.60 \mathrm{a}$ & $14.50 \mathrm{ab}$ \\
\hline $\begin{array}{c}\text { Rizolex-T + Roundup } \\
\text { star } \\
\end{array}$ & $0.14 \mathrm{ab}$ & $0.12 \mathrm{ab}$ & $22.70 \mathrm{a}$ & $15.80 \mathrm{ab}$ \\
\hline Control & $0.13 b$ & $0.10 \mathrm{~b}$ & $16.13 b$ & $8.97 \mathrm{c}$ \\
\hline
\end{tabular}

Means designed by the same letter at each cell are not significantly different at the $5 \%$ level according to Duncan's multiple range test.

\section{Chlorophyll content:}

Results illustrated in Table (9) exhibit that all the tested garlic treatments exerted significant effects on the chlorophyll content of geranium plants. The highest chlorophyll A values $\left(16.20,15.40 \mathrm{mg} \mathrm{g}^{-1}\right)$, chlorophyll B $\left(12.00,15.40 \mathrm{mg} \mathrm{g}^{-1}\right)$ and carotenoids content $\left(5.47,4.27 \mathrm{mg} \mathrm{g}^{-1}\right)$ were recorded in the treatment of the fungicide + the herbicide followed by treatment of intercropping of garlic with geranium plants without significant difference between both. The corresponding mean values of chlorophyll A were $15.87 \& 14.80 \mathrm{mg} \mathrm{g}^{-1}$, chlorophyll $\mathrm{B}, 11.67 \&$ $11.60 \mathrm{mg} \mathrm{g}^{-1}$. Meanwhile, contents of carotenoids were $5.13 \& 3.87 \mathrm{mg} \mathrm{g}^{-1}$, respectively for the two plant cuts. Treated geranium cuttings and spraying the plants by garlic extract gave the lowest impact on leaf chlorophyll content with an average of $14.77 \& 14.00 \mathrm{mg} \mathrm{g}^{-1}, 10.33 \& 9.90 \mathrm{mg} \mathrm{g}^{-1}$ for chlorophyll A and B and $4.40 \& 2.80 \mathrm{mg} \mathrm{g}^{-1}$ leaf fresh weight for carotenoids content, respectively for the two plant cuts. The same trend was also true for the second growing season. 
Table (9): Effect of different garlic treatments on chlorophyll content and carotenoids in geranium leaves during the two growing seasons (2016 and 2017).

\begin{tabular}{|c|c|c|c|c|c|c|}
\hline \multirow[t]{2}{*}{ Treatments } & \multicolumn{2}{|c|}{$\begin{array}{l}\text { Chlorophyll A } \\
\left(\mathrm{mg} \mathrm{g}^{-1}\right)\end{array}$} & \multicolumn{2}{|c|}{$\begin{array}{l}\text { Chlorophyll B } \\
\left(\mathrm{mg} \mathrm{g}^{-1}\right)\end{array}$} & \multicolumn{2}{|c|}{$\begin{array}{c}\text { Carotenoids (mg } \\
\mathrm{g}^{-1} \text { ) }\end{array}$} \\
\hline & $1^{\text {st }}$ cut & $2^{\text {nd }}$ cut & $1^{\text {st }}$ cut & $2^{\text {nd }}$ cut & $1^{\mathrm{st}} \mathrm{cut}$ & $2^{\text {nd }}$ cut \\
\hline \multicolumn{7}{|c|}{$1^{\text {st }}$ season } \\
\hline $\begin{array}{l}\text { Cutting treatment } \\
+ \text { foliar spray }\end{array}$ & $14.77 \mathrm{de}$ & $14.00 \mathrm{de}$ & $10.33 \mathrm{c}$ & $9.90 \mathrm{c}$ & $4.40 \mathrm{c}$ & $2.80 \mathrm{de}$ \\
\hline Intercropping & $15.87 \mathrm{ab}$ & $14.80 \mathrm{~b}$ & $11.67 \mathrm{ab}$ & $11.60 \mathrm{a}$ & $5.13 \mathrm{ab}$ & $3.87 \mathrm{ab}$ \\
\hline $\begin{array}{l}\text { Soil amended } \\
\text { with garlic }\end{array}$ & $15.60 \mathrm{bc}$ & $14.53 b c$ & $11.47 \mathrm{~b}$ & $10.80 \mathrm{~b}$ & 4.93abc & $3.43 \mathrm{bc}$ \\
\hline $\begin{array}{l}\text { Soil amended } \\
\text { with garlic }+ \\
\text { foliar spray }\end{array}$ & $15.27 \mathrm{~cd}$ & $14.20 \mathrm{~cd}$ & $11.13 b$ & $10.60 \mathrm{~b}$ & $4.67 b c$ & $3.20 \mathrm{~cd}$ \\
\hline $\begin{array}{l}\text { Rizolex-T + } \\
\text { Roundup star }\end{array}$ & $16.20 \mathrm{a}$ & $15.40 \mathrm{a}$ & $12.00 \mathrm{a}$ & $11.53 \mathrm{a}$ & $5.47 \mathrm{a}$ & $4.27 \mathrm{a}$ \\
\hline Control & $14.47 \mathrm{e}$ & $13.53 \mathrm{e}$ & $9.93 c$ & $9.53 c$ & $3.60 \mathrm{~d}$ & $2.43 \mathrm{e}$ \\
\hline \multicolumn{7}{|c|}{$2^{\text {nd }}$ season } \\
\hline $\begin{array}{l}\text { Cutting treatment } \\
+ \text { foliar spray }\end{array}$ & $14.00 \mathrm{bc}$ & $13.80 \mathrm{~d}$ & $9.67 d$ & $9.53 \mathrm{c}$ & $3.93 \mathrm{~d}$ & $3.37 \mathrm{~cd}$ \\
\hline Intercropping & $15.17 \mathrm{a}$ & $14.57 \mathrm{ab}$ & $10.77 \mathrm{ab}$ & $10.47 \mathrm{a}$ & $4.73 \mathrm{ab}$ & $4.53 \mathrm{a}$ \\
\hline $\begin{array}{l}\text { Soil amended } \\
\text { with garlic }\end{array}$ & $14.43 b$ & $14.27 \mathrm{bc}$ & $10.33 b c$ & $10.17 \mathrm{ab}$ & $4.60 \mathrm{bc}$ & $4.00 \mathrm{~b}$ \\
\hline $\begin{array}{l}\text { Soil amended } \\
\text { with garlic }+ \\
\text { foliar spray }\end{array}$ & $14.37 \mathrm{~b}$ & $13.97 \mathrm{~cd}$ & $10.00 \mathrm{~cd}$ & $10.00 \mathrm{~b}$ & $4.40 \mathrm{c}$ & $3.63 b c$ \\
\hline $\begin{array}{c}\text { Rizolex-T + } \\
\text { Roundup star }\end{array}$ & $15.40 \mathrm{a}$ & $14.93 \mathrm{a}$ & $11.20 \mathrm{a}$ & $10.50 \mathrm{a}$ & $4.93 \mathrm{a}$ & $4.67 \mathrm{a}$ \\
\hline Control & $13.37 \mathrm{c}$ & $13.00 \mathrm{e}$ & $8.57 \mathrm{e}$ & $9.33 \mathrm{c}$ & $3.33 \mathrm{e}$ & $2.97 \mathrm{~d}$ \\
\hline
\end{tabular}

Means designed by the same letter at each cell are not significantly different at the $5 \%$ level according to Duncan's multiple range test.

\section{Essential oils constituent:}

Quality of essential oil depends on the relative composition of different ingredients. Data in Table (10) indicate that the content of principle ingredients was influenced by different garlic treatments, which increased the main chemical compositions of the essential oil compared to the untreated control.

Gas chromatographic analysis of the volatile oil compounds from geranium essential oil herb, revealed the existence of 14 compounds from the identified compounds. The main components in geranium herb oil samples studied were citronellol (27.58-

Egypt. J. Phytopathol., Vol. 47, No. 1 (2019) 
$36.93 \%)$, geraniol (17.14-23.79\%), sesquiterpenols (5.01-12.46\%), limonene (2.21$7.58 \%)$ and linalool (1.58-7.64\%). A comparison between composition of geranium oil shows that plants which intercropped with garlic gave the highest content of citronellol (36.93 \& 31.99\%) and geraniol (23.79 \& $23.52 \%$ ), respectively for the two plant cuts followed by treatment of garlic-amended soil and spraying geranium plants by garlic extract as it gave $34.34 \& 22.53 \%$, respectively in the first plant cut and $31.62 \& 22.14 \%$, respectively in the second plant cut. The maximum values of sesquiterpenols $(9.00 \& 12.46 \%)$, limonene $(7.57 \& 6.78 \%)$ and linalool $(7.64 \& 7.01 \%)$ were obtained as a result of treatment of garlicamended soil and spraying geranium plants by garlic extract, respectively for the two plant cuts.

Table (10): GC analysis for volatile oils obtained from the $1^{\text {st }}$ and $2^{\text {nd }}$ cuts in the $1^{\text {st }}$ season (2016).

\begin{tabular}{|c|c|c|c|c|c|c|c|c|c|c|c|c|}
\hline \multirow{3}{*}{ Compounds } & \multicolumn{12}{|c|}{ Treatments } \\
\hline & \multicolumn{2}{|c|}{$\begin{array}{c}\text { Cutting } \\
\text { treatment + } \\
\text { foliar spray }\end{array}$} & \multicolumn{2}{|c|}{ Intercropping } & \multicolumn{2}{|c|}{$\begin{array}{c}\text { Soil amended } \\
\text { with garlic }\end{array}$} & \multicolumn{2}{|c|}{$\begin{array}{c}\text { Soil amended } \\
\text { with garlic }+ \\
\text { foliar spray }\end{array}$} & \multicolumn{2}{|c|}{$\begin{array}{l}\text { Rizolex-T }+ \\
\text { Roundup star }\end{array}$} & \multicolumn{2}{|c|}{ Control } \\
\hline & $\begin{array}{l}1^{\text {st }} \\
\text { cut }\end{array}$ & $\begin{array}{l}2^{\text {nd }} \\
\text { cut }\end{array}$ & $\begin{array}{l}1^{\text {st }} \\
\text { cut }\end{array}$ & $\begin{array}{l}2^{\text {nd }} \\
\text { cut }\end{array}$ & $\begin{array}{l}1^{\text {st }} \\
\text { cut }\end{array}$ & $\begin{array}{l}2^{\text {nd }} \\
\text { cut }\end{array}$ & \begin{tabular}{|l|}
$1^{\text {st }}$ \\
cut
\end{tabular} & $\begin{array}{l}2^{\text {nd }} \\
\text { cut }\end{array}$ & $\begin{array}{l}1^{\text {st }} \\
\text { cut }\end{array}$ & $\begin{array}{l}2^{\text {nd }} \\
\text { cut }\end{array}$ & $\begin{array}{c}1^{\mathrm{st}} \\
\text { cut }\end{array}$ & $\begin{array}{l}2^{\text {nd }} \\
\text { cut }\end{array}$ \\
\hline$\alpha$-pinene & 2.36 & 2.29 & 2.34 & 1.63 & 3.28 & 0.86 & 1.01 & 1.70 & 1.48 & 4.68 & 2.11 & 1.38 \\
\hline P-Cymene & 1.24 & 4.54 & 3.53 & 2.99 & 3.74 & 1.63 & 4.66 & 4.66 & 3.37 & 1.28 & 2.34 & 3.59 \\
\hline Limonene & 2.98 & 3.36 & 6.11 & 5.86 & 3.26 & 2.97 & 7.58 & 6.31 & 5.40 & 5.05 & 2.21 & 2.24 \\
\hline Linalool & 6.30 & 3.95 & 7.57 & 6.78 & 1.58 & 3.46 & 7.64 & 7.01 & 4.67 & 3.03 & 2.21 & 2.37 \\
\hline$\alpha$-terpineol & 0.68 & 0.74 & 4.13 & 6.85 & 7.54 & 6.97 & 0.78 & 5.95 & 6.64 & 5.03 & 7.37 & 7.43 \\
\hline Citrone & 30.65 & 29.53 & 36.93 & 31.99 & 33.98 & 31.10 & 34.34 & 31.62 & 33.74 & 27.58 & 30.34 & 28.59 \\
\hline Geraniol & 20.15 & 18.00 & 23.79 & 23.52 & 21.67 & 21.65 & 22.53 & 22.14 & 21.98 & 18.77 & 18.19 & 17.14 \\
\hline Geranial & 1.48 & 2.94 & 3.79 & 2.48 & 4.64 & 3.40 & 1.25 & 3.09 & 4.06 & 2.79 & 2.32 & 2.57 \\
\hline Eugenol & 1.83 & 1.98 & 1.76 & 1.37 & 1.19 & 1.60 & 2.56 & 3.54 & 2.79 & 1.63 & 2.05 & 1.70 \\
\hline$\beta$-caryophyllene & 2.17 & 2.31 & 2.79 & 1.02 & 2.71 & 3.01 & 1.82 & 1.83 & 2.40 & 3.43 & 2.74 & 2.01 \\
\hline Citronellylformate & 2.84 & 1.93 & 1.98 & 2.87 & 2.53 & 2.58 & 1.05 & 2.68 & 2.65 & 4.24 & 1.88 & 2.04 \\
\hline Geranylformate & 2.26 & 2.07 & 2.80 & 3.71 & 2.61 & 1.84 & 2.39 & 2.10 & 3.21 & 2.65 & 2.22 & 3.72 \\
\hline Sesquiterpenols & 7.66 & 8.97 & 8.81 & 12.18 & 7.99 & 7.32 & 9.00 & 12.46 & 8.37 & 9.42 & 5.01 & 8.38 \\
\hline Rose oxide & 1.38 & 1.43 & 2.37 & 1.91 & 1.84 & 4.91 & 2.42 & 3.31 & 2.95 & 2.35 & 1.31 & 2.89 \\
\hline Unknown & 4.37 & 3.48 & 3.66 & 4.93 & 4.23 & 4.61 & 3.90 & 4.15 & 5.20 & 5.81 & 5.42 & 5.05 \\
\hline Total & 100.0 & 100.0 & 100.0 & 100.0 & 100.0 & 100.0 & 100.0 & 100.0 & 100.0 & 100.0 & 100.0 & 100.0 \\
\hline
\end{tabular}

\section{D is c us sion}

Many researchers have been carried out experiments to find alternative to fungicides and safe methods to control plant diseases. Thus, natural plant products are important sources of new agro-chemicals for the control of plant diseases. It is known that various natural plant products can reduce populations of soil borne pathogens and control disease development. These plant products have potentials as 
environmentally safe alternatives and as components in integrated pest management programs (Slusarenko et al., 2008). Our study demonstrated that all the tested garlic treatments significantly caused different degrees of reducing basal stem rot and root rot of geranium compared to the control. These results are in accordance with those obtained by several investigators (Haggag and Abdel-Latif, 2001; Prasad et al., 2010; Mohamed et al., 2012 and Adolf, 2016). Intercropping garlic with geranium plants showed the highest efficacy in this concern. This result is in line with the reports of Shahiduzzaman (2015) and Yasmin (2016). The active component was identified as allicin, a diallylthiosulfinate (2-propenyl-2-propenethiol sulfonate) (Rahman et al., 2006). Two hypotheses explain the mechanisms responsible for the suppression of soil borne pathogens by garlic cultivation have been proposed. The first hypothesis implicates the involvement of antimicrobial compounds released from roots of garlic plants (Zhang et al., 2013). It is well known that the antifungal properties of Alliaceous plants are due to the sulfur content and other phenolic compounds (Rivlin, 2001). The second hypothesis, based on the known importance of the soil microbiome in the suppression of soil-borne diseases (Rosenzweig et al., 2012 and Shen et al., 2015), implicates microorganisms associated with garlic plants in the suppression of soil borne diseases. Intercropping with garlic plants $(A$. sativum), changes the bacterial diversity and structure of the soil (Zhou et al., 2011 and Ahmad et al., 2013). Rhizosphere microbial communities are directly influenced by the root exudates of host plants and differ across plant species (Gardner et al., 2011 and Li et al., 2014). Therefore, they hypothesized that rhizospheres of Alliaceous plants harbor unique microbial communities and that some of the predominant microorganisms are involved in the suppression of soil borne diseases induced by garlic cultivation.

The present study demonstrated that intercropping garlic with geranium significantly reduced broomrape to extend level compared to the untreated control. This result is in line with the reports of Acharya (2013). Abu-Shall and Ragheb (2014) reported a reduction in O.crenata emerged spikes amounting to $42 \%$ when the cultivar Aquadulce was intercropped with garlic. The possible role of non-host test crops in reducing Orobanche seed viability could be that i) crops exude stimulant(s) for suicidal seed germination (Sauerborn, 1991) and ii) crops exude chemicals, which in association with suitable microorganisms acquire stimulatory nature for broomrape seed germination (Wegmann et al., 1991).

Meanwhile, the present study demonstrated that intercropping garlic with geranium significantly increased the vegetative growth of geranium plants. This result is in agreement with that reported by Noghani et al. (2013). Cheng et al. (2016) reported that diallyl disulfide (DADS) is a volatile organosulfur compound derived from garlic (A. sativum L.), which is responsible for promotion root growth of tomato plants through increased the cell length of root meristem and enhanced the mitotic activity of meristematic cells in seedling root tips as indicated from cytological observations and thus increased the cell numbers in the meristem and Egypt. J. Phytopathol., Vol. 47, No. 1 (2019) 
enlarged the length of the meristematic zone in the root. Also they observed that the content of gibberellic acid and indole-3-acetic acid in tomato roots increased as the diallyl disulfide (DADS) concentration increased which may be caused by promotion of the expression of IAA biosynthesis genes FZYs (Expósito-Ródriguezet al., 2007, 2011).Exogenous auxins are thought to induce rapid elongation in plant tissues by increasing the mechanical extensibility of the cell wall (Cosgrove, 1993; Karcz et al., 1999; Martínez et al., 2011 and Polak et al., 2011). Gibberellins (GAs) play indispensable roles in seed germination, normal root development and keeping roots long and slender (Thomas et al., 2005).

\section{Conclusion}

It was observed from this study that using garlic as intercropping with geranium or soil amendment and spraying the plants by its extract effectively controlled the basal stem and root rot as well as decreased the broomrape number, weight and enhanced the growth, oil and chemical composition of geranium plant.

\section{References}

Abbes, Z.; Kharrat, M.; Delavault, P.; Simier, P. and Chaïbi, W. 2007. Field evaluation of the resistance of some faba bean (Vicia faba L.) genotypes to the parasitic weed Orobanche foetida Poiret. Crop Prot., 26: 1777-1784.

Abebe, G.; Sahile, G. and Al-Tawaha, A.M. 2005. Evaluation of potential trap crops on Orobanche soil seed bank and tomato yield in the Central Rift Valley of Ethiopia. World J. Agric. Sci., 1(2): 148-151.

Abu-Shall, A.M.H. and Ragheb, E.I.M. 2014. Management of Orobanche crenata using trap crops and Phytomyza orobanchia Kalt. in broad bean (Vicia faba) field in Egypt. Egypt. J. Biol. Pest Contr., 24(1): 217-223.

Acharya, B.D. 2013. Relationship between seed viability loss and seed bank reduction of Orobanche aegyptiaca Pers. using non-host crops. Ecoprint., 20: 97-106.

Adolf, K.M. 2016. Root rot of geranium transplants and its biological control. Int. J. Agric. Technol., 12(5): 899-914.

Ahmad, I.; Cheng, Z.; Meng, H.; Liu, T.; Wang, M.; Ejaz, M. and Wasila, H. 2013. Effect of pepper-garlic intercropping system on soil microbial and bio-chemical properties. Pak. J. Bot., 45(2): 695-702.

Cheng, F.; Cheng, Z.; Meng, H. and Tang, X. 2016. The garlic allelochemicaldiallyl disulfide affects tomato root growth by influencing cell division, phytohormone balance and expansin gene expression. Fronti. in Plant Sci., 7: 1-16.

Cosgrove, D.J. 1993. Wall extensibility: its nature, measurement and relationship to plant cell growth. New Phytol., 124: 1-23. 
Dorman, H. and Deans, S. 2000. Antimicrobial agents from plants: antibacterial activity of plant volatile oils. J. Appl. Microbiol., 88: 308-316.

Eiasu, B.K.; Steyn, J.M. and Soundy, P. 2012. Physiomorphological response of rose-scented geranium (Pelargonium spp.) to irrigation frequency. South Afr. J. Bot., 78: 96-103.

El-Gamal, N.G. 1995. Relationship between rhizospheric microflora and fungi causing some root diseases of geranium plants. M.Sc. Thesis, Fac. of Agric., Ain Shams Univ., Cairo, Egypt pp: 92.

El-Mougy, N.S. and Abdel-Kader, M.M. 2007. Antifungal effect of powdered spices and their extracts on growth and activity of some fungi in relation to damping-off disease control. J. Plant Prot. Res., 47(3): 267-278.

Expósito-Ródriguez, M.; Borges, A.A.; Borges-Pérez, A.; Hernandez, M. and Perez, J.A. 2007. Cloning and biochemical characterization of ToFZY, a tomato gene encoding a flavin monooxygenase involved in a tryptophan- dependent auxin biosynthesis pathway. J. Plant Growth Regul.,26:329-340.

Expósito-Ródriguez, M.; Borges, A.A.; Borges-Pérez, A. and Pérez, J.A. 2011. Gene structure and spatiotemporal expression profile of tomato genes encoding YUCCA-like flavin monooxygenases: the ToFZY gene family. Plant Physiol. Biochem., 49: 782-791.

Gardner, T.; Acosta-Martinez, V.; Senwo, Z. and Dowd, S.E. 2011. Soil rhizosphere microbial communities and enzyme activities under organic farming in Alabama. Diversity, 3: 308-328.

Guenther, G. 1961. The Essential Oils VIII. Robert E.D. Nastrand Comp. Inc. Toronto, New York, London. Pp 569.

Haggag, W.M. and Abdel-Latif, F.M. 2001. Interaction between vasicular arbuscular mycorrhizae and antagonistic biocontrol microorganisms on controlling root rot disease incidence of geranium plants. J. Biol. Sci., 1(12): 1147-1153.

Hussain, M.A.; Mukhtar, T. and Kayani, M.Z. 2011. Efficacy evaluation of Azadirachta indica, Calotropis procera, Datura stramonium and Tagetes erecta against root-knot nematodes Meloidogyne incognita. Pak. J. Bot., 43: 197-204.

Jackson, M.L. 1958. Soil Chemical Analysis. New Jersy Prentice-Hall. Inc. Englewood, Cliffs, N.J. USA. pp. 285.

Joel, D.M.; Hershenhorn, J.; Eizenberg, H.; Aly, R.; Ejeta, G.; Rich, P.J.; Ransom, J.K.; Sauerborn, J. and Rubiales, D. 2007. Biology and management of weedy root parasites. Hort. Rev., 33:267-350.

Egypt. J. Phytopathol., Vol. 47, No. 1 (2019) 
Kalra, A.; Parameswaran, T.N. and Ravindra, N.S. 1992. Influence of planting date on plant losses and yield responses of geranium (Pelargonium graveolens) to root rot and wilt. The J. Agric. Sci., 118(3): 309-314.

Karcz, W.; Luthen, H. and Bottger, M. 1999. Effect of IAA and 4-Cl-IAA on growth rate in maize coleoptiles segments. Acta Physiol. Plant, 21: 133-139.

Kebreab, E. and Murdoch, A.J. 1999. Effect of moisture and temperature on the longevity of Orobanche seeds. Weed Res., 39: 199-211.

Kharrat, M.; Abbes, Z. and Amri, M. 2010. A new faba bean small seeded variety Najeh tolerant to Orobanche registered in the Tunisian Catalogue. Tunis. J. Plant Prot., 5: 125-130.

Li, X.; Ding, C.; Hua, K.; Zhang, T.-L.; Zhang, Y.-N.; Zhao, L.; Yang, Y.; Liu, J.-G. and Wang, X.-X. 2014. Soil sickness of peanuts is attributable to modifications in soil microbes induced by peanut root exudates rather than to direct allelopathy. Soil Biol. and Biochem., 78: 149-159.

Linke, K.H.; Sauerborn, J. and Saxena, M.C. 1991. Host-parasite relationships: Effect of Orobanche crenata seed banks on development of the parasite and the yield of faba bean. Angewandte Botanisk, 65: 229-238.

Lüpez-Granados, F. and Garcfa-Torres, L. 1991. Eight years study on population evolution of Orobanche crenata in Vicia faba L. In: Proc. of the $5^{\text {th }}$ Int. Symp. on Parasitic Weeds, (Ransom, J.K., L.J. Musselman, A.D. Worhsam and C. Parker, Eds). Nairobi: CIMMYT., pp. 352-355.

Martínez, J.A.; Valdes, R.; Gómez-Bellot, M.J. and Bañón, S. 2011. Effects of indole-3-acetic acid on Botrytis cinerea isolates obtained from potted plants. Commun. Agric. Appl. Biol. Sci., 76: 643-651.

Matthews, A.J. 1995. Geranium leaves for cracked nipples. Aust. J. Hospital Pharm., 25: 538-539.

Mercado, W. and Rodriguez, R.P. 2001. Fungicidas para el manejo del cancro y la pudricion de raiz de los cafetos. J. Agr. Univ. Puerto Rico, 85:187-195.

Mohamed, E.F.; El-Refaei, M.I.; Hilal, A.A. and Abdel-Wahed, A.G. 2012. Using of tissue culture to decrease the deterioration of productivity of Pelargonium graveolens plant in Egypt. Researcher, 4(6): 25-35.

Motsa, N.M.; Soundy, P.; Steyn, J.M.; Learmonth, R.A.; Mojela, N. and Teubes, C. 2006. Plant shoot age and temperature effects on essential oil yield and oil composition of rose-scented geranium (Pelargonium sp.) grown in South Africa. J. Essent. Oil Res., 18: 106-110. 
Noghani, M.; Mashayekhi, K.; Shakouri, M.J. and Mousavizadeh, S.J. 2013. The study the usefulness production garlic, in intercropping with the pea in Gorgan Region. Int. Res. J. Appl. Basic Sci., 6(11): 1761-1763.

Parker C. 2009. Observations on the current status of Orobanche and Striga problems worldwide. Pest Manag. Sci., 65: 453-459.

Parker, C. 2012. Parasitic weeds: A World challenge. Weed Sci., 60: 269-276.

Polak, M.; Tukaj, Z. and Karcz, W. 2011. Effect of temperature on the doseresponse curves for auxin-induced elongation growth in maize coleoptile segments. Acta Physiol. Plant, 33: 437-442.

Prasad, D.; Singh, A.; Singh, K.P.; Bist, S.; Tewari, A. and Singh, U.P. 2010. The role of phenolic compounds in disease resistance in geranium. Arch. Phytopathol. Plant Prot., 43(7): 615-623.

Prins, C.L.; Vieira, I.J.C. and Freitas, S.P. 2010. Growth regulators and essential oil production. Braz. Soc. Plant Physiol., 22: 91-102.

Rahman, M.S.; Al-Sheibani, H.I.; Al-Riziqi, M.H.; Mothershaw, A.; Guizani, N. and Bengtsson, G. 2006. Assessment of the anti-microbial activity of dried garlic powders produced by different methods of drying. Int. J. Food Prop., 9: 503513.

Rajeswara Rao, B.R.; Kaul, P.N.; Mallavarapu, G.R. and Ramesh, S. 1996. Effect of seasonal changes on biomass yield and terpenoid composition of rose scented geranium (Pelargonium species). Biochem. Syst. Ecol., 24: 627-635.

Rivlin, R.S. 2001. Historical perspectives on the use of garlic. J. Nutr., 131(3): 951S-954S.

Rosenzweig, N.; Tiedje, J.M.; Quensen, J.F.; Meng, Q. and Hao, J.J. 2012. Microbial communities associated with potato common scab suppressive soil determined by pyrosequencing analyses. Plant Dis., 96: 718-725.

Sauerborn, J. 1991. Parasitic Flowering Plants, Ecology and Management. Supraregional Project, GTZ, University of Hohenheim, Institute of Plant Production in the Tropics and Subtropics. Verlagjosefmargraf Scientific book.

Sealy, R.; Evans, M.R. and Rothrock, C. 2007. The effect of a garlic extract and root substrate on soil borne fungal pathogens. Hort. Technology, 17(2): 169-173.

Shahzad, S. and Ghaffar, A. 1992. Root rot and root knot disease complex of mungbean and its biological control. pp. 349-256. In: Status of Plant Pathology in Pakistan. Proc. National Symp., (Eds.) A. GhafFar \& S. Shahzad. Department of Botany, University of Karachi, Karachi-75270, Pakistan.

Egypt. J. Phytopathol., Vol. 47, No. 1 (2019) 
Shahiduzzaman, M. 2015. Efficacy of fungicides and botanicals in controlling foot and root rot of lentil. Bangl. J. Agril. Res., 40(4): 711-715.

Shen, Z.; Ruan, Y.; Xue, C.; Zhong, S.; Li, R. and Shen, Q. 2015. Soils naturally suppressive to banana Fusarium wilt disease harbor unique bacterial communities. Plant Soil, 393: 21-33.

Singh, M. 1999. Effect of soil moisture regime, nitrogen and modified urea materials on yield and quality of geranium (Pelargonium graveolens) grown on alfisols. $J$. Agric. Sci., 133: 203-207.

Singh, M.; Singh, U.B.; Ram, M.; Yadav, A. and Chanotiya, C.S. 2013. Biomass yield, essential oil yield and quality of geranium (Pelargonium graveolens $\mathrm{L}$. Her.) as influenced by intercropping with garlic (Allium sativum L.) under subtropical and temperate climate of India. Ind. Crop Prod., 46: 234-237.

Slusarenko, A.; Patel, A. and Portz, D. 2008. Control to plant diseases by natural products: Allicin from garlic as a case study. Eur. Plant Pathol., 121:313-322.

Snedecor, G.W. and Cochran, W.G. 1989. "Statistical Methods". $8^{\text {th }}$ ed. Iowa State Univ. Press, Ames, Iowa, USA, 251 pp.

Thomas, S.G.; Rieu, I. and Steber, C.M. 2005. "Gibberellin metabolism and signaling," in Plant Hormones, edG. Litwack (San Diego, CA: Elsevier Academic Press Inc), 289-338.

Wegmann, K.; Von Elert, E.; Harloff, H.J. and Stadler, M. 1991. Tolerance and resistance to Orobanche. In: Progress in Orobanche Research. (eds.) Wegmann, K. and L.J. Musselman. EberhardKarls Universitat.

Yasmin, S. 2016. In vitro evaluation of botanical extracts against some soil and seed borne fungi of economic importance. J. Agri. Ecolo. Res. Int., 8(2): 1-11.

Zhang, H.; Mallik, A. and Zeng, R.S. 2013. Control of panama disease of banana by rotating and intercropping with Chinese chive (Allium tuberosum Rottler): role of plant volatiles. J. Chem. Ecol., 39: 243-252.

Zhou, X.; Yu, G. and Wu, F. 2011. Efects of intercropping cucumber with onion or garlic on soil enzyme activities, microbial communities and cucumber yield. Eur. J. Soil Biol., 47: 279-287.

Corresponding author: Ghebrial, E.W.R.

E-mail: dr.emanwageeh@yahoo.com

(Received 28/04/2019;

in revised form 12/05/2019) 
تأثير معاملات الثوم المختلفة على مكافحة أمراض عفن الثن

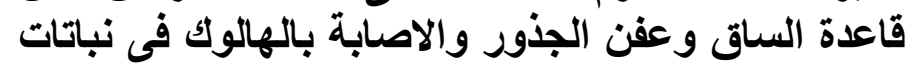

أحمد عبد العزيز أحمد دويدار' وعادل جلال محمود قناوى' وايمان

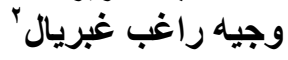

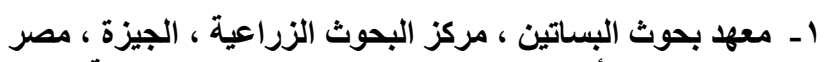

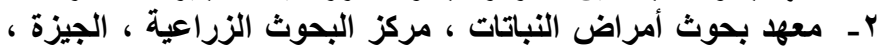

مصر

اجريت التجربة فى المزرعة البحثية بمحطة بحوث البساتين بسدس -

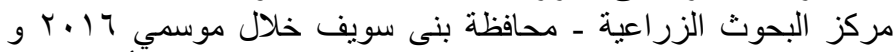

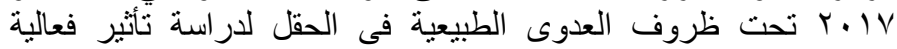

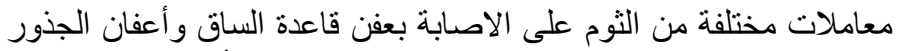

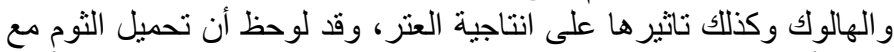

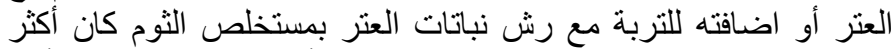

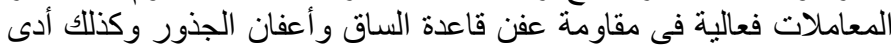

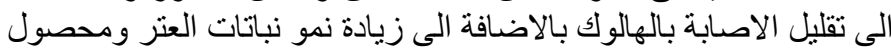

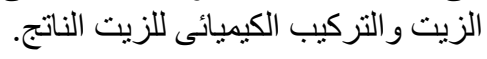

Egypt. J. Phytopathol., Vol. 47, No. 1 (2019) 